\title{
CARS/ALK Fusion Protein
}

National Cancer Institute

\section{Source}

National Cancer Institute. CARS/ALK Fusion Protein. NCI Thesaurus. Code C99872.

A fusion protein ( $680 \mathrm{aa}, \sim 75 \mathrm{kDa}$ ) that is encoded by the CARS/ALK fusion gene. This protein contains 606 amino acids from the $\mathrm{N}$-terminus of the cysteinyl-tRNA synthetase, cytoplasmic protein and the cytoplasmic domain of the ALK tyrosine kinase receptor protein. 